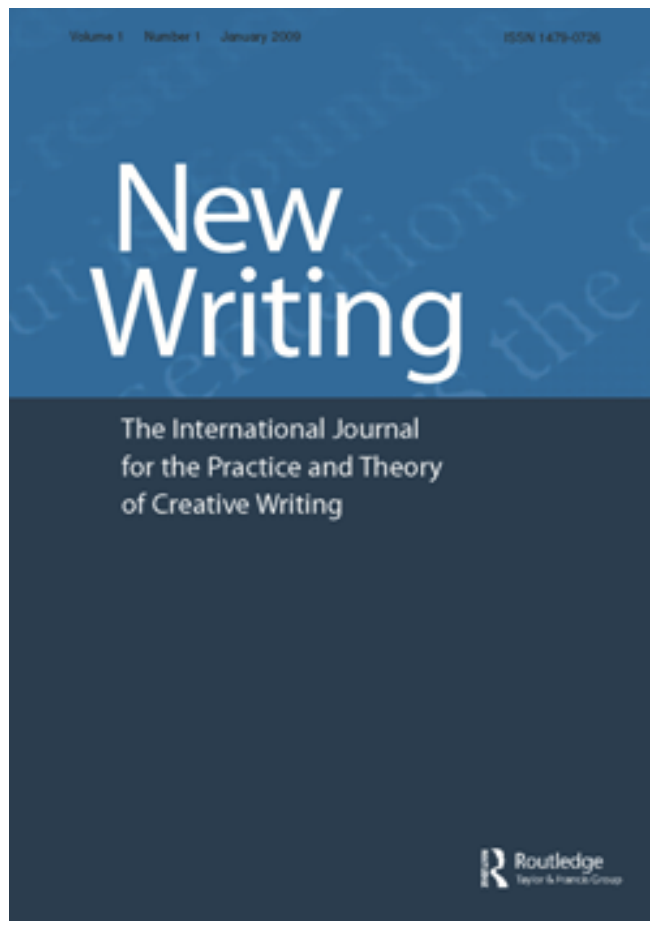

\title{
'Who are you to judge my writing?': Student collaboration in the co-construction of assessment rubrics
}

\begin{tabular}{|c|l|}
\hline Journal: & $\begin{array}{l}\text { New Writing: The International Journal for the Practice and Theory of } \\
\text { Creative Writing }\end{array}$ \\
\hline Manuscript ID & NEW-1632.R1 \\
\hline Manuscript Type: & Paper \\
\hline Keywords: & $\begin{array}{l}\text { rubrics, co-construction, Collaboration, enhanced student learning, } \\
\text { creative writing, Academic writing }\end{array}$ \\
\hline & $\begin{array}{l}\text { Collaborative models of involving students in the co-construction of } \\
\text { assessment rubrics are rare. Inviting students to take part actively in } \\
\text { the design of assessment rubrics is one method of filling this research } \\
\text { gap, garnering a shared understanding of assessment requirements. } \\
\text { Rubrics traditionally are constructed by educators, based on set criteria, } \\
\text { in order to streamline grading more cohesively and equitably. But } \\
\text { research demonstrates that assessment rubric use is of more benefit to } \\
\text { the educator in grading, than to the student in undertaking the } \\
\text { assessment task - the educator understands requirements but specific } \\
\text { requirements are not clear to the student. Using a multiple case study } \\
\text { research approach incorporating a modified Delphi method to gather } \\
\text { expert views on rubrics, the study outlined in this paper explores the } \\
\text { outcomes of collaborating with creative writing students at the rubric } \\
\text { design stage of the assessment process. This paper discusses the rubric } \\
\text { co-construction process facilitated by a writing lecturer and a team of } \\
\text { students from one university who took part in collaborating and } \\
\text { developing a creative writing assessment rubric. The processes adopted } \\
\text { to implement this co-construction are reported, the products of which }\end{array}$ \\
\hline
\end{tabular}


were distributed to a 250-student cohort, and reflects on the value of this pedagogical innovation.

\section{SCHOLARONE \\ Manuscripts}




\section{'Who are you to judge my writing?': Student collaboration in the co- construction of assessment rubrics}

Collaborative models of involving students in the co-construction of assessment rubrics are rare. Inviting students to take part actively in the design of assessment rubrics is one method of filling this research gap, potentially garnering a shared understanding of assessment requirements. Rubrics traditionally are constructed by educators, based on set criteria, in order to streamline grading more cohesively and equitably. But research demonstrates that assessment rubric use is usually of more benefit to the educator in grading, than to the student in undertaking the assessment task - the educator understands requirements but often specific requirements are not clear to the student. Using a multiple case study research approach which incorporated a modified Delphi method to gather expert views on rubrics, the study outlined in this paper explores the outcomes of collaborating with creative writing students at the rubric design stage of the assessment process. This paper discusses the rubric coconstruction process facilitated by a writing lecturer and a team of students from one university who took part in collaborating and developing a creative writing assessment rubric. The processes adopted to implement this co-construction process are reported, the products of which were distributed to a 250 -student cohort, and reflects on the value of this pedagogical innovation.

Keywords: rubrics; co-construction; collaboration; enhanced student learning; creative writing

Funding details: This work was supported by the Office for Learning and Teaching (OLT) Australia under the Seed Grant Program [grant number SD15-5203].

Ethics approval details: The research reported in this project was approved by the Human Research Ethics Committees at three institutions: 1) Avondale College of Higher Education, NSW. HREC reference number:2016:40. Ethics approval granted on 29 September 2016;

2) University of Technology Sydney, NSW. HREC reference number: ETH16-0910. Ethics approval granted on 1 November 2016; and

3) Charles Sturt University, NSW. HREC reference number: H16157. Ethics approval granted on 7 December 2016.

\section{'By what standards are you judging here?'}

'What is certain is that writing assessment is now constructed as a rhetorical act: as its own agent with responsibilities to all its participants' (Yancy 1999, 501).

Now a Professor of Creative Writing at Bath Spa University, the novelist, playwright and screenwriter Fay Weldon offers this reflection on assessment practice in her discipline area:

Creative Writing tends to worry and bemuse, however vaguely, those who work in other disciplines, and why it has taken so long to come to the foreground as a subject. And this is also why students, particularly at postgraduate level threaten to turn to litigation. 'Why didn't you give me an A? What's wrong with it? Who 
are you to judge my writing? By what standards are you judging here?' You point out that there are artistic standards in literature, that you yourself are part of the process of defining those standards. They snarl. $(2010,169)$

Weldon's comments highlight a common perception associated with grading students' creative writing artefacts, chiefly that the process is a subjective activity shaped and determined largely by a lecturer's own literary preferences. The image evoked by her vignette is one of a perceived power differential where students feel removed from a generative and vested participation in the initial assessment design process.

One of the difficulties of assessing creative writing, as Rodriguez contends, is that this '... has been based on the idea that it is emotive' $(2008,171)$. Importantly, she makes a key distinction between emotional investment and literary aesthetics: 'But the merit of student writers' intentions or their depth of feeling cannot be confused with their final product' (Rodriguez 2008, 171). Arguably one of the primary roles a creative writing educator can play is helping students understand the ways in which their writing can be assessed fairly. Kroll posits that assessment can actually bring 'some advantages' because

students receive a reasonable estimate of their performance (as opposed to their ability) in a certain limited context (the course or the assignment). They can learn in which areas they function well and in which they need to improve. Further, they receive feedback about how to improve. (Kroll 1997, 1) Part of this feedback process may utilise assessment rubrics which can provide informative descriptions of good and bad work (Andrade 2005), but more importantly these kinds of instructional tools might be employed to assist students to better understand the required outcomes of an assessment task before they begin writing so they can strategically focus their work accordingly, rather than engage with criteria after the marking process. 


\section{Traditional use of rubrics and new opportunities}

Returning briefly again to Weldon's praxis, her description of the marking process for creative writing may resonate with some educators who are both simultaneously challenged and comforted by the use of a marking criteria:

$\mathrm{An}$ ' $\mathrm{A}$ ' is an ' $\mathrm{A}$ ' the exceptional quality shines through. $\mathrm{A}$ ' $\mathrm{C}$ ' is a ' $C$ ' ordinariness wins. And then there you have to put a number on it. The cold hand of Quality and Standards falls on your warm response and starts to squeeze the life out of it.

I was used to hostile journalists or demanding editors, but not to anxious undergraduates, large eyes full of potential tears. What did most to soothe my state of alarm, when I came face to face with students for the first time, was the existence of the official university feedback sheet, designed by mathematicians and adapted by my colleagues in Creative Writing, of course. Here was a conference of judges predigested for the machinery. There were boxes to tick. Machinery adores a tick-box. (Weldon 2010, 171-172)

While she notes that 'the love of tick-boxes has almost ruined teaching in our schools and brought our teachers on to the streets in revolt', she also sees that 'the tradition has its merits' offering this:

Consider work in its component parts and the machine understands what you, the marker, are looking for, and your students can be clear as to which aspects of their writing are working, and what aren't, where to relax, where more work is required. Tick the boxes right and get an overall impression of the student's achievement.

Going across the page of the grid find boxes under seven headings: excellent, very good, good, average, satisfactory, unsatisfactory, unacceptable. The latter two amounting to 'fails.' (Weldon 2010, 171-172)

However useful tick boxes might be in navigating and applying standards to a final product, this activity is often linked to justifying an outcome to a student (and a department examination board) rather than teaching class members to fully understand and appreciate the nuances and specificities of marking criteria.

To make 'long lasting' changes in the way in which we assess student writing, Huot argues this can only occur when we 'attempt to change the theory which drives our practices and attitudes toward assessment' $(1996,551)$. Revising some of those key practices and attitudes could involve the ways we have traditionally designed and used rubrics. Taking a critical stance on what kinds of rubrics we have previously used and for what purpose invites us to think more openly about Andrade's theorisation that 
'Rubrics used only to assign final grades represent not only a missed opportunity to teach but also a regrettable instance of the teacher-as-sole-judge-of-quality model that puts our students in a position of mindlessness and powerlessness' $(2005,29)$.

The potential learning opportunities that are associated with engaging students in assessment design was one of the key motivations in undertaking this research project. While previous studies have espoused the benefits for lecturers of using rubrics (Stevens \& Levi, 2011; Wolf \& Stevens, 2007), and the benefits of engaging students in the assessment design process (Biggs, 2012; Rust, O’Donovan, \& Price, 2005; Wilson $\&$ Fowler, 2005), little research has been conducted about the benefits of rubrics that are co-constructed with students.

As James et al write: 'Students' active contribution to their own learning has been recognised as an important enabler of engagement and a signal of their motivation to learn' (James, Krause, \& Jennings 2010: 43). Creating opportunities where students can co-construct rubrics for assessment tasks enables them to be more motivated and engaged, it might also become a space where students can '... develop capabilities to operate as judges of their own learning' (Boud \& Molloy 2013: 698). To extend recent investigations into the role of rubrics in student learning, and to explore the affordances of engaging students with the design of tools used to assess student learning in university contexts, a four phase study was designed and implemented. The four phases of the study are now outlined, along with commentary about one of the six cohorts of students who participated in the study.

\section{The preparatory phase}

The study adopted a multiple case study design which involved six cohorts of students, and their lecturers, across three higher education institutions. To determine the most effective characteristics of assessment rubrics, an extensive literature review was undertaken and followed by a modified Delphi technique (Keeney, Hasson, \& McKenna, 2006) which gathered specialised advice from a panel of experts in assessment design. Subsequently, a checklist of Effective Rubric Characteristics (ERCs) was constructed (Williams et al 2017) with the intention to use this checklist during a later phase of the study when rubrics were co-constructed by students and their lecturers.

In preparation for the co-construction phase, six cohorts of students and their lecturers were selected along with a subject that included an appropriate assessment task. One of the study's six cohorts was located at the University of Technology Sydney. The subject elected was a first year, mandatory creative writing unit called 
Imagining the Real, a creative nonfiction subject incorporating two assessments with a cohort of 250 students. The subject was due to be offered during UTS' spring semester beginning August, 2017. To allow time for the rubric co-construction process to be undertaken, an email was issued to students in May, inviting them to participate in the rubric co-construction process with their lecturer. The rubric was intended to be used with the second assessment task of the subject. Of the total cohort of students, 13 originally indicated an interest in engaging in the rubric co-construction process but this number was reduced to five students once dates were scheduled for the co-construction meetings.

\section{Co-construction process with students}

Early in the semester members of the research team met with the students to explain the project, answer questions and distribute consent forms. During this time, a questionnaire was also administered to the lecturer and the students (a pre-survey) to determine their pre-conceived ideas about using rubrics for assessment purposes. Next, the lecturer worked with the students to co-construct the assessment rubric by meeting on two occasions. Face-to-face meetings were supplemented by various electronic modes between the co-constructing academic and the team of students until the rubrics were finalised. The details of the co-construction process are now described.

Using the Imagining the Real UTS Online forum, the co-constructing academic set up a separate tab entitled OLT Rubric Research. This tab was visible to all students and lecturers involved in the subject during semester. This online forum spearheaded the co-construction phase during the first meeting of the team - it was efficient to screen it in the classroom used for the meeting, and methodically explore it together. It was important to the academic that the students understand the rationale behind assessment criteria, and what Course Intended Learning Outcomes (CILOs) and Subject Learning Outcomes (SLOs), as these acronyms appear on all UTS subject outlines, mapped against letters, numbers and qualitative sentences pertaining to criteria (see Table 1).

The session continued with an explanation of the Australian Qualifications Framework (AQF), the national policy which regulates Australian education and training qualifications. Discussing the specifications for generic Bachelor degrees, the students were able to see the trickle-down effect, from government policy to School learning outcomes.

The next step was to discuss rubrics and give some salient examples. This was divided into the two types - holistic and analytic - and the students agreed that most had experienced both at primary school, but never at UTS. After this discussion, the 
results from preparatory phase of the research project were shown and discussed Effective Rubric Characteristics (ERC) (see Table 2).

Then a table of advice from rubric experts was explored. Table 3 contains advice to teachers and students who engage in the co-construction of rubrics. This advice was drawn from recommendations provided to the project team by a panel of national and international specialists who had expertise in rubrics and assessment.

Finally, before we began co-constructing our rubric, a table of cautions was shown and discussed with the students (see Table 4). These cautions were drawn from recommendations provided to the project team by a panel of national and international specialists who had expertise in rubrics and assessment.

The next stage of the session was to go through clearly the requirements of Assessment 2, with stated criteria, weighting, SLOs and CILOs (see Table 5). The academic handed out grade tiers so the students could begin to unpack the grading protocols (see Table 6). Finally, the academic presented the student team with the current and original rubric used for grading this assessment (see Table 7).

Comments from students were immediate and acerbic: 'nobody strives to fail why is it the first thing we read?'; How do you recognise unsatisfactory. What does that mean?; We want examples - how to achieve?'; 'Too many words'; 'We don't want to read down'; 'Can we use the readings as exemplars?'; 'Who's not aiming for an HD?'. At this stage, one of the students went to the computer podium and began creating their own rubric. It was an organic and dynamic atmosphere - the students completely disrupted and inverted the concept of traditional rubrics. What they aimed for was ultimately called an Instructional Rubric (see Table 8).

The student co-constructors insisted on including exemplars from their weekly readings to demonstrate the elements of each criterion. They chose three over-arching terms - Language, Peer-review and Aesthetics to organise the criteria. And they forensically took apart the original rubric, honing in on the language and creating a criteria table they understood and all agreed upon. This is an essentially aspirational guide to achieving the highest standard of work - a High Distinction.

It was important to the students that the rest of the Imagining the Real cohort received not only their newly devised Instructional Rubric, but also the Grade Tier table and the table demonstrating how the subject aligns with both its SLOs and CILOs. The academic agreed that the Instructional Rubric package catered to the needs of the students but she still needed to provide a grading rubric for her fellow lecturers, including casual lecturers. Almost reluctantly as they were so pleased with their Instructional Rubric for their peers, the students agreed to unpack and devise a new 
language around criteria for a grading rubric for lecturers, mapping it to the language of their Instructional Rubric. This was done mostly electronically across the next month, with backwards and forwards emails aggregating changes and suggestions. The final document for grading appears in Table 9.

After the rubrics were constructed, the lecturer was interviewed and completed a post-survey to collect data about her views of the rubric co-construction process. On a nearby date, the students also completed a post-survey and participated in a focus group interview during which they reported their views about the co-construction process.

\section{Reflections on the collaborative process from the student co-constructors}

One of the key motivations for students joining the co-construction team working with their lecturer/unit co-ordinator and class members is represented by the following reflection:

... part of the reason I got into this research is because I thought it was really valuable to have that extra time with your peers and your convener. It was a good opportunity to get to know her better and get to understand the subject better. Just having a connection with teachers and knowing them better. And knowing students better too.

In this sense, such observations about collaboration and engagement concur with James et al who tell us that

In addition to the broader institutional factors contributing to student engagement, there is strong evidence to show the importance of student contact with academic staff...the importance of personal contact with first year students in small groups is key to enhancing students' engagement with learning and with the university community as a whole. (James, Krause, and Jennings 2010, 42)

Along with revealing this key relational dynamic of the process, responses to the focus group questions also produced a range of other themes which are identified below.

\section{'Getting started a bit better': clarity in navigating expectations and ensuring transparency}

Jackson and Larkin argue that 'You can help students achieve clarity by asking what is meant by the evaluation criteria before students begin using the rubric' (Jackson \& Larkin 2002, 43), and this consideration informed early discussions around the coconstruction process. One respondent articulated a shared pedagogical aim of the group 
indicating the importance of receiving clearly communicated expectations via a rubric when commencing an assessment task for writing disciplines:

I'm like, what does that even mean because they usually use what we started with and they are very unclear to what we are meant to be doing. Working in creative subjects ... they are very open ended as to what you can do. I think it's really important to be clear on what you're being marked on.

Some of the participants disclosed that rubrics were a tool they were familiar with from previous high school experience, but had not been a common feature in all of their tertiary units to date. Consequently, participation in the co-construction process had helped demystify and translate criteria-based marking often employed by writing lecturers:

You think about it and initially you always think, I'm going to get this mark or this is what I need to do to get this mark. You aim high and stuff but as it comes closer maybe you have constraints on time or whatever and you realise maybe I haven't ticked that box or that box.

Another participant signalled a new appreciation for using rubrics proactively rather than as a reactive recourse for interpreting how the work had been assessed: '...we could look at a rubric to mark our work, but now when I look at a rubric it is more like a prompt. I am able to look at things and go, oh, I should look at structure or points of view or whatever. I am able to get started a bit better'.

Crucially, students saw the process of co-construction as promoting transparency and providing a navigational reference on how to best proceed in producing quality work. One participant described their learning experience this way: I understand for a teacher they want things to be transparent, they want you to understand exactly how they are marking things, but that might not necessarily help you at the start of an assignment. Starting out it is a lot to think about. I don't really need a whole page of information that goes into all the details. It's not really where you want to start an assignment, you just want a little clarity to 
start. I don't need to think about all that when I start an assignment, I just want to know how to get from point A to point B with the best possible mark.

This emphasis on providing clarity without overwhelming extraneous detail highlighted students' preferences for a learning environment which intentionally considered their goal to thrive without producing instructional material and rubrics shrouded in academic jargon.

Working directly with the lecturer also enabled students to appreciate the diversity of needs constellating the construction and use of a rubric: '... [that process] really helped because we understood that teachers have a completely different need than we do'. While acknowledging their lecturer functioned within a different context to their own, the group identified one of the co-construction benefits as increased knowledge of specific elements and how they could develop requisite skills to progress their work:

I thought it was interesting to get a deeper perspective on what the criteria was because when I look at the assessment I just see one sentence and one sentence then when you start analysing it you see like a paragraph and more than one sentence. It was a bit more in depth and it made me see what I needed to do better.

This aspect of the project's outcomes points to students' appreciation for developing a better understanding of assessment task expectations, that is, 'getting started a bit better'. This benefit of the rubric co-construction process aligns with the work of Boud and his associates (Boud \& Associates, 2010; Boud \& Molloy, 2013) who endorse engaging students in the assessment process. While the students appreciated the clarity provided by the experience of co-constructing the rubric alongside their lecturer, they also reported on valuing the group approach to working on this task with other students and their lecturer. 


\section{Team building and connectedness}

It was interesting to observe the productive and collegial nature of the coconstruction process with one of the participants describing the scenario in these terms: ... we were all at the table and everyone was sitting there shouting our instructions out but it was pretty orderly really. I was surprised at how much we got done given the format in that time. You would assume it would just turn into a bunch of people yelling out their own opinion but it wasn't.

Another student co-constructor commented that 'I think it was useful to have like a think tank where we put in an idea and everyone else helps shift it and sculpt it and see where that can be applied to the situation. That mentality and that type of environment will be helpful in the future'. This description of a 'think tank' where active learning and spontaneous contributions are evaluated and acted upon in real time provided a direct contrast to previous experiences where they observed 'that rubrics are generally emailed out and they are never discussed'. As Williams et al observe, 'Even if teachers are intentional in their attempts to explain to students how rubrics are most effectively used, most rubrics are essentially teacher-driven' (Williams et al 2017, 425).

In contrast to top-down or teacher-centred assessment approaches, the methodology implemented in this study engaged both the lecturer and the students within the same context in which they were working on the same task: the development of a marking rubric, or tool or tools, which would also be instructional for students. One of the important outcomes of working with students as part of a rubric co-construction team was the increased level of engagement, with one of the participants noting, '.. it provided a little more of a personal relationship and then in turn gave us a better understanding of the assessment and the rubric and the process of the whole thing. I didn't feel so detached anymore'. This potential to increase students' engagement in and ownership of their learning during such a process has not been reported at length in 
assessment literature, with most rubric-focused studies reporting on the benefits associated specifically with assessment.

\section{Lecturer's reflections on the co-construction process and student-centred learning}

The lecturer involved in the co-construction process indicated that the use of rubrics is a relatively new practice in her discipline area at the university: 'I've begun to use them more in the last year but not for student viewing. Just for grading. I use it really when I have casuals to have some sort of equity across the way we grade in such disparate seminars and classes'.

In presenting the co-construction team with her original rubric for critique, comment and change, she made an important observation about vacating a position of power and transferring autonomy to students: 'That was the beginning of me having to lose any vestige of ownership over the process. It had to be their process... I learned so much from them'. We can see here an example of Donnelly's encouragement to 'embrace' new 'paradigms' because they help position 'creative writing as a proactive knowledge-based discipline, one which situates student learning at its centre' (Donnelly 2015, 229). The centering of students in this rubric process did not diminish the lecturer's role, rather she found the collaboration an expansive activity: 'I learned so very much. I always learn something from my students, but this was intense learning in a very intimate space. I really appreciate the experience'.

Focusing on student learning as the driving purpose behind using assessment rubrics that have been co-constructed by those using them also appeared to impact the quality of student learning - as perceived by both the lecturer and the students. This finding aligns with the work of Jones, Allen, Dunn, and Brooker who reported "a statistically significant improvement in grades ' (2016: 138) after conducting a study in which students were guided in effectively using rubrics to improve their performance. Similarly, our results in this study demonstrate the participants' intentions on achieving a high level of learning. The lecturer involved in the co-construction process said: 
I think what they've created isn't a traditional Rubric. We've called it an instructional Rubric. I think it's a hybrid instructional, aspirational Rubric because all they are really interested in is the high distinction. Not for just getting the highest marks but to make their creative work the best it can possibly be. So, I would call it aspirational.'

The students' commitment to producing quality work directly mirrored the lecturer's aspirations for her class. The co-construction process provided an opportunity for the lecturer to see these aspirations tangibly realised in the production of the final artefact:

They don't want to know how to fail, they want to know how to be the best they can be and that is so intuitive and it makes so much sense. I suppose rubrics before that to me were very flat on the page, but this one kind of bubbles. I can see how the students are going to be able to relate to it.

Part of its 'bubbling' and relatability is the way in which this rubric helped reformulate some of the previously nebulous grading descriptors. The lecturer offered a valuable insight into progressing this challenge: 'They were saying things to me like, "What does good mean? How do you get from good to very good? What does very good mean?" I think it's very hard to articulate that. I mean, I've been grading things for decades'. Along with her students, the lecturer also sought clarity and concrete exemplars to further elucidate previously broad and vague adjectives to describe students' writing projects.

As previously indicated, the students feel proud of what they created as they could see their instructional rubric helping other students navigate and unpack criteria more intentionally and with reference points to assist. Likewise, the lecturer was gratified by the way the students unpacked her tradional rubric and re-created 
something more germane for the student cohort: 'the thing that really endeared me was that they used language to do it. They really focused on the language. I was quite proud of that because this was a writing degree'.

As well as using language to refine the rubric, the final product appeared to benefit both the lecturer and the student by promoting students' ownership of their learning and enhancing the lecturer's insight into her students' experience. At the centre of good teaching practice are strategies directed towards students flourishing and gaining expertise. The rubric co-construction process not only produced a rubric more directly aligned with achieving such goals, but the lecturer also noted it promoted a more empathic and direct appreciation of student experience and aspiration:

I believe it has enhanced my teaching by allowing me to get a glance through their eyes. They care so much that they want to make their artefact as good as it can be. It means that much to them.

\section{Conclusion}

In their research on student perspectives on rubric-referenced assessment, Andrade and $\mathrm{Yu}$ argue that 'Rubrics are often used to grade student work but they can serve another, arguably more important, role as well: Rubrics can teach as well as evaluate' (Andrade \& Du 2005, 1). In our context, the co-construction process involving a lecturer and a cohort of student-participants has enabled students and their lecturer to simultaneously learn about the role of a rubric. While previous studies about rubrics have largely focused upon the advantages of using rubrics for lecturers or students, this study contributes further to the discussion about rubrics by providing evidence about how students and lecturers work together within the same context to co-construct rubrics.

Of course, the study had its limitations; while the timing worked within the semester at UTS, other institutions often require rubrics in place months before a subject is presented, making it difficult to work within the cohort undertaking the 
subject. The team also was working with students who were self-selected - it would be interesting to co-opt on the spot ideas on rubrics from within an entire cohort. We also hoped to garner data on moderation perceptions from both lecturers and students.

Assessments are usually moderated at university via best practice, but managing issues of confidentiality in giving students access to each others' grades became ethically insurmountable. Our final report signals this is one area which could create a possible nexus for future research.

An exciting aspect of this project is the ongoing opportunity to share practical reflections with other academics working in this discipline. Specifically, practical implications have emerged about how the assessment of writing might move from some of the 'subjective' perceptions and challenges described by Fay Weldon to the wider use of co-constructed rubric tools where students have high input and investment. It is our hope that this particular research project advances Donnelly's meta goal that 'Through research insights and new understandings, knowledge spirals upward from the individual to the creative writing domain where it is communicated and justified' (2015: 223). And most significantly, 'Given the recursive and fluid path of the knowledge spiral, new knowledge also flows from the larger writing community back to creative writers, and knowledge creation transforms pedagogically' (Donnelly 2015, 223). The flow of knowledge as a means to shift and transform pedagogical practice also invites intentional thinking about '... where we should travel, where we could travel - as well as where we most likely will travel in creative writing education' (Harper $2014,60)$. In co-navigating and journeying with her students to new knowledge territories and practices, the lecturer offered this signpost and invitation to other wouldbe travellers:

From the very minute they opened their mouths I was stepping into their world. It's like I was on the other end of the table. I wasn't standing up near the 
podium, I was sitting down with them looking at what it must sound like when I

talk to them about their criteria and what is necessary in their work.

\section{References}

Andrade, Heidi. G. 2005. 'Teaching with rubrics: the good, the bad, and the ugly', College Teaching. 53(1), 27-30.

Andrade, Heidi. G., Du, Ying. 2005. 'Student perspectives on rubric-referenced assessment', Practical Assessment, Research \& Evaluation. 10(3), 1-11.

Biggs, John. (2012). What the student does: Teaching for enhanced learning. Higher Education Research \& Development, 31(1), 39-55.

Boud, David., \& Associates. (2010). Assessment 2020: Seven propositions for assessment reform in higher education. Retrieved from Australian Learning and Teaching Council (ALTC): http://www.olt.gov.au/resource-student-assessmentlearning-and-after-courses-uts-2010

Boud, David., \& Molloy, Elizabeth. 2013. 'Rethinking models of feedback for learning: the challenge of design', Assessment \& Evaluation in Higher Education, 38(6), 698712 .

Donnelly, Dianne. 2015. 'Creative Writing as Knowledge: What's Assessment Got to Do with It?', New Writing, 12 (2), 222-237. doi. 10.1080/14790726.2015.1042390

Harper, Graeme. 2014. The Future for Creative Writing, John Wiley \& Sons, Incorporated. Chapter 3 'Creative Writing Educating' pp 53-70.

Huot, Brian. 1996. 'Toward a New Theory of Writing Assessment', College Composition and Communication, 47(4), 549-566. doi:10.2307/358601

Jackson, Cynthia. W., \& Larkin, Martha. J. 2002. 'Teaching Students to Use Grading Rubrics', TEACHING Exceptional Children, 35(1), 40-45.

doi:10.1177/004005990203500106

James, Richard., Krause, Kerri-Lee., \& Jennings, Claire. 2010. The first-year experience in Australian universities: Findings from 1994 to 2009. Melbourne: Centre for the Study of Higher Education, The University of Melbourne.

Jones, Lorraine, Allen, Bill, Dunn, Peter, \& Brooker, Lesley. (2017). Demystifying the rubric: a five-step pedagogy to improve student understanding and utilisation of marking criteria. Higher Education Research \& Development, 36(1), 129-142. doi: https://doi.org/10.1080/07294360.2016.1177000

Keeney, Sinead, Hasson, Felicity, \& McKenna, Hugh. (2006). Consulting the oracle: Ten lessons from using the Delphi technique in nursing research. Journal of Advanced Nursing, 53(205-212).

Kroll, Jeri. 1997. “A or C: Can We Assess Creative Work Fairly?” TEXT 1 (1). http://www. textjournal.com.au/april97/kroll.htm 
Rodriguez, Alicia. 2008. The 'Problem' of Creative Writing: Using Grading Rubrics Based On Narrative Theory as Solution', New Writing, 5 (3): 167-177. doi: $\underline{10.1080 / 14790720802209963}$

Rust, Chris, O’Donovan, Berry, \& Price, Margaret. (2005). A social constructivist assessment process model: how the research literature shows us this could be best practice. Assessment \& Evaluation in Higher Education, 30(3), 231-240.

Stevens, Dannelle D, \& Levi, Antonia J. (2011). Introduction to rubrics: An assessment tool to save grading time, convey effective feedback, and promote student learning: Stylus Publishing, LLC.

Weldon, Fay. 2010. 'On Assessing Creative Writing', New Writing' 6 (3): 168-174. doi: $\underline{10.1080 / 14790720903556734}$

Williams, Anthony., Northcote, Maria., Morton, Jason., and Seddon, John. 2017. "Towards engaging students in curriculum transformation: What are the effective characteristics of rubrics?" In R.G.Walker \& S.B.Bedford (Eds.), Research and Development in Higher Education: Curriculum Transformation, 40: 423-433. http://www.herdsa.org.au/research-and-development-higher-education-vol-40-423

Wilson, Kethia, \& Fowler, Jane. (2005). Assessing the impact of learning environments on students' approaches to learning: Comparing conventional and action learning designs. Assessment \& Evaluation in Higher Education, 30(1), 87-101.

Wolf, Kenneth, \& Stevens, Ellen. (2007). The role of rubrics in advancing and assessing student learning. The Journal of Effective Teaching, 7(1), 3-14.

Yancey, Kathleen Blake. 1999. "Looking back as we look forward: Historicizing writing assessment". College Composition and Communication, 50(3), 483. Retrieved from https://search.proquest.com/docview/220709610?accountid=26359

\section{Disclosure statement.}

No potential conflict of interest was reported by the authors.

\section{Word count}

5,532 
Table 1. UTS Creative Writing CILOs and SLOs for Imagining the Real

UTS SCHOOL OF COMMUNICATION

Bachelor of Communication (Creative Writing)

1. Professional Readiness

1.1 Possess a well-developed awareness of professional practice in the context of the communication industries

1.2 Apply theoretically-informed understanding of the communication industries in independent and collaborative projects across a range of media

2. Critical and Creative Inquiry

2.1 Possess information literacy skills to locate, gather, organise and synthesise information across diverse platforms to inform the understanding of the communication industries

2.2 Be reflexive critical thinkers and creative practitioners who are intellectually curious, imaginative and innovative; with an ability to evaluate their own and others' work

\section{International and Intercultural Engagement}

3.1 Demonstrate an awareness and knowledge of global contexts and openness to cultural exchange

3.2 Employ professional skills responsibly and respectfully in a global environment

\section{Indigenous Competencies}

4.1 Possess a critical understanding of the importance of Aboriginal and Torres Strait Islander peoples within contemporary Australian politics, history and culture

4.2 Integrate knowledge of Indigenous issues in professional practices and engage responsibly in communicating with and about Indigenous people and communities

\section{Active Citizenship}

5.1 Possess the awareness of ethical practice in the personal, political and professional contexts of civil society

5.2 Possess the skills to behave ethically in personal and professional contexts

\section{Effective Communication}

6.1 Possess well-developed skills and proficiencies to communicate and respond effectively and appropriately across different contexts

6.2 Demonstrate digital literacy and production skills across a range of media and media texts

\section{Subject learning objectives (SLOs)}

a. Explore and practise creative and imaginative writing

b. Reflect upon and analyse the complexities of writing creative non-fiction

c. Identify and describe the accepted limits of writing the real

d. Explore the possibilities of non-fiction writing

e. Collaborate with peers

f. Edit critically their own work and that of their peers 
Table 2. Effective Rubric Characteristics (ERC)

\begin{tabular}{|c|c|c|}
\hline Category & \multicolumn{2}{|c|}{ Effective rubric characteristic } \\
\hline \multirow[t]{15}{*}{ Purpose of rubrics } & 1. & Rubrics are useful as instructional tools for providing assessment guidelines to students. \\
\hline & 2. & Rubrics help in providing quality feedback to students. \\
\hline & 3. & Rubrics are a time-efficient way for teachers to provide feedback to students. \\
\hline & 4. & An effective rubric reduces marker bias. \\
\hline & 5. & Rubrics provide indicators for success and descriptions of these indicators. \\
\hline & 6. & Rubrics provide indicators for success and descriptions of these indicators. \\
\hline & 7. & Rubrics help focus student effort. \\
\hline & 8. & Rubrics are useful as assessment tools (e.g., for grading). \\
\hline & 9. & Rubrics are useful as instructional tools (e.g., for teaching and learning). \\
\hline & 10. & Rubrics help teachers communicate intended learning outcomes. \\
\hline & 11. & Rubrics help students to plan their approach to an assignment. \\
\hline & 12. & Rubrics promote consistent marking of student assessments. \\
\hline & 13. & Students' use of rubrics improves the standard of their work. \\
\hline & 14. & The use of rubrics reduces marking subjectivity. \\
\hline & 15. & The purpose of a rubric is better understood if it is co-constructed by teachers and students. \\
\hline Marking criteria & 16. & Rubric marking criteria should align with the learning outcomes of an assessment. \\
\hline \multirow[t]{3}{*}{ Performance descriptors } & 17. & Performance descriptors should be informative of what is good and bad work. \\
\hline & 18. & Performance descriptors should be worded concisely. \\
\hline & 19. & Performance descriptors should reflect clear gradations of quality. \\
\hline Feedback narrative & 20. & Students benefit from feedback comments at the end of a rubric. \\
\hline \multirow[t]{8}{*}{ Rubric development } & 21. & The effectiveness of a nubric should be tested against benchmarked performance standards. \\
\hline & 22. & Rubrics should be created not based on personal demands but rather on discipline standards. \\
\hline & 23. & Rubric creators should be sensitive to the use of academic discourse (e.g. terminology or jargon). \\
\hline & 24. & Rubric creators should avoid vague and ambiguous language. \\
\hline & 25. & Peer-marking should occur among teachers to assess the effectiveness of a rubric. \\
\hline & 26. & The co-construction of a rubric provides learning opportunities for students. \\
\hline & 27. & $\begin{array}{l}\text { Co-creating a rubric allows teachers and students to have a shared understanding of the expectations of an } \\
\text { assessment. }\end{array}$ \\
\hline & 28. & The wording of a rubric is more clearly understood by students when they are a part of constructing the rubric. \\
\hline \multirow[t]{9}{*}{ Rubric application } & 29. & A rubric should be provided to students prior to them starting an assessment. \\
\hline & 30. & An effective rubric provides students with the opportunity to self-evaluate their own work before submission. \\
\hline & 31. & The purpose of a rubric should be explained to students. \\
\hline & 32. & Teachers should receive instruction in how to use the rubric prior to marking. \\
\hline & 33. & Students should receive instruction in how to use the rubric prior to submission. \\
\hline & 34. & Examples of exemplar work should be provided to students to illustrate work of high quality. \\
\hline & 35 . & Rubrics do not replace good instruction. \\
\hline & 36. & $\begin{array}{l}\text { Students should be provided with opportunities to practice their use of the rubric (e.g. provision of work of } \\
\text { different standards to mark). }\end{array}$ \\
\hline & 37. & Students should be encouraged to read the rubric after a grade is provided. \\
\hline
\end{tabular}


Table 3. Advice from rubric experts

\begin{tabular}{|c|c|}
\hline Category & Advice from rubric experts about co-constructing rubrics \\
\hline Shared understanding & $\begin{array}{l}\text { Getting both students and teachers to calibrate their understandings of a graduate attributes, performance level } \\
\text { descriptors and marking criteria is absolutely crucial when co-constructing rubrics. }\end{array}$ \\
\hline Wording & A rubric will be more useful if the wording for all sections is negotiated with the students. \\
\hline Educative & $\begin{array}{l}\text { Rubrics can be used to help teach important disciplinary vocabulary and concepts. This enables students to play a } \\
\text { more meaningful role in their own assessment. }\end{array}$ \\
\hline \multirow[t]{2}{*}{ Validity } & $\begin{array}{l}\text { Teachers may need to enter the co-construction stage with a considered starting point or rubric draft (to help ensure } \\
\text { the validity and reliability is built in). }\end{array}$ \\
\hline & The performance descriptors for an assessment task need to be constructively aligned to the learning outcomes. \\
\hline Assessment complexity & The number of marking criteria depends on the complexity of the assessment task. \\
\hline \multirow[t]{2}{*}{$\begin{array}{l}\text { Allocation of scores or marks } \\
\text { to marking criteria }\end{array}$} & $\begin{array}{l}\text { Some marking criteria matter more than others. Information should be shared with students about which criteria are } \\
\text { most important. }\end{array}$ \\
\hline & $\begin{array}{l}\text { In terms of allocating marks or weightings to individual marking criteria, it's important to remember that "the } \\
\text { whole is more than the sum of the parts" and an overall professional judgement needs to be made more important } \\
\text { than the individual allocation of marks for each criterion. }\end{array}$ \\
\hline Must pass & $\begin{array}{l}\text { Depending on what is being assessed, some criteria within rubrics or some rubrics on the whole might have a "must } \\
\text { pass" proviso (e.g., safety skills in the use of a science laboratory). }\end{array}$ \\
\hline Order of performance levels & $\begin{array}{l}\text { Since we read from left to right and we want students to read the best descriptors first, so arrange them left/high to } \\
\text { right/low. } \\
\text { Since we read from left to right, we want students to finish reading with the highest descriptor, so arrange them } \\
\text { left/low to right/high. } \\
\text { [Because this characteristic has been recommended by experts in two opposing ways, we plan to discuss this with } \\
\text { the students during the co-construction process.] }\end{array}$ \\
\hline \multirow[t]{2}{*}{ Performance level descriptors } & Performance level descriptors need to define the work done, not the person doing the work. \\
\hline & $\begin{array}{l}\text { Performance level descriptors need to be written in a way that is relevant to the course level (e.g., first year, } \\
\text { postgraduate), to the discipline and the standard required for the particular task. } \\
\text { [Note: This is important for teachers and students, but teachers would need to lead on this when the co-constructing } \\
\text { and using rubrics with students.] }\end{array}$ \\
\hline
\end{tabular}




\section{Table 4. Cautions from rubric experts}

\begin{tabular}{|c|c|}
\hline Category & Cautions from rubric experts about co-constructing rubrics \\
\hline Power relationships & $\begin{array}{l}\text { When students work with teachers to co-construct rubrics, teachers should be aware that students may feel intimidated. Strategies must be } \\
\text { put in place to reduce the risk of this. }\end{array}$ \\
\hline Other lecturers & $\begin{array}{l}\text { Be careful to avoid communicating the expectation that only good lecturers negotiate rubrics with their students to avoid the } \\
\text { misconception that a lecturer who does not engage in rubric co-construction isn" t necessarily a bad lecturer. }\end{array}$ \\
\hline Student attitudes & $\begin{array}{l}\text { Students often think it is the role of teachers to control the whole assessment process. Students may feel they are not in a position to make } \\
\text { informed judgements about writing assessment criteria and standards. }\end{array}$ \\
\hline Student knowledge & $\begin{array}{l}\text { Teachers should be aware that students may not have an understanding of the Australian Quality Framework (AQF), threshold learning } \\
\text { outcomes or course learning outcomes. Students may also lack appreciation of the incremental development of skills across varied levels } \\
\text { of a course. }\end{array}$ \\
\hline Time required & $\begin{array}{l}\text { The co-constrinction of the rubric takes up class time, unless the co-constrtuction is scheduled for out-of-class time (as is being done in this } \\
\text { project). }\end{array}$ \\
\hline \multirow[t]{3}{*}{ Types of rubrics } & $\begin{array}{l}\text { Holistic rubrics can lead to confusion as they may not communicate quality in ways that are comprehensible. } \\
\text { Holistic rubrics with qualitative performance descriptors can lead to significant inconsistency in marking. }\end{array}$ \\
\hline & $\begin{array}{l}\text { Analytic rubrics can lead to tokenistic engagement with quality Holistic rubrics can lead to confusion as they may not communicate } \\
\text { quality in ways that are comprehensible }\end{array}$ \\
\hline & $\begin{array}{l}\text { All discussion of effective rubric characteristics, advice and cautions needs to be prefaced with the proviso of "Depending on the type of } \\
\text { rubric ...." and/or "Depending on the type of assessment task..." }\end{array}$ \\
\hline $\begin{array}{l}\text { Performance level } \\
\text { headings }\end{array}$ & $\begin{array}{l}\text { Try to avoid use of the word "averag" in performance level headings since it is based on comparison to something that is not defined. } \\
\text { Average of what? }\end{array}$ \\
\hline Criteria & $\begin{array}{l}\text { When developing marking criteria, academics bring their own hidden criteria with them, despite what each of the marking criteria } \\
\text { specifies. }\end{array}$ \\
\hline Scoring & $\begin{array}{l}\text { Allocating a score to each of the marking criteria can cause problems (inconsistency, invalidity, etc.). However, the opposite idea (giving } \\
\text { a quantitative mark for each criterion is also acknowledged as something students would like: "Students of course will like rubrics which } \\
\text { include a column for scoring each criterion, because they provide a sense of certainty..... but that is not our ultimate aim!) }\end{array}$ \\
\hline Assessment complexity & It is difficult to construct a succinct rubric that describes all the nuances and variations that may be inherent in a complex assessment task. \\
\hline $\begin{array}{l}\text { Risk of not looking at } \\
\text { rubrics across the course }\end{array}$ & $\begin{array}{l}\text { A whole-of-curriculum approach to developing skills/threshold learning outcomes may not be achieved if students and teachers } \mathrm{co} \\
\text { consistruct rubrics for their courses. }\end{array}$ \\
\hline
\end{tabular}


Table 5. Criteria, weighting, SLOs and CILOs for Assessment 2

\begin{tabular}{|c|c|c|c|}
\hline \multicolumn{4}{|c|}{$\begin{array}{l}\text { Imagining the Real: Standard UTS Guidelines } \\
\text { This table outlines how the course aligns with Subject and Course objectives }\end{array}$} \\
\hline Criteria & $\begin{array}{c}\text { Weight } \\
\%\end{array}$ & Subject Learning Outcomes (SLOs) & Course Learning Outcomes (CILOs) \\
\hline $\begin{array}{l}\text { Inventiveness \& } \\
\text { originality of writing }\end{array}$ & 40 & $\begin{array}{l}\text { a, } \mathbf{d} \\
\text { a: Explore \& practise creative \& } \\
\text { imaginative writing } \\
\text { d: Explore possibilities of non-fiction } \\
\text { writing }\end{array}$ & $\begin{array}{l}2.2 \\
\text { Be reflexive critical thinkers \& creative practitioners who are intellectually curious, } \\
\text { imaginative \& innovative; with an ability to evaluate their own \& others' work }\end{array}$ \\
\hline $\begin{array}{l}\text { Structure \& consistency of } \\
\text { writing }\end{array}$ & 40 & $\begin{array}{l}\text { a, } \mathbf{d} \\
\text { a: Explore \& practise creative \& } \\
\text { imaginative writing } \\
\text { d: Explore possibilities of non-fiction } \\
\text { writing }\end{array}$ & $\begin{array}{l}6.1 \\
\text { Possess well-developed skills \& proficiencies to communicate \& respond } \\
\text { effectively \& appropriately across different contexts }\end{array}$ \\
\hline $\begin{array}{l}\text { Integration of self- } \\
\text { assessment \& critical } \\
\text { feedback }\end{array}$ & 5 & $\begin{array}{l}\text { e, f } \\
\text { e: Collaborate with peers } \\
\text { f: Edit critically their own work \& } \\
\text { that of their peers }\end{array}$ & $\begin{array}{l}2.2 \\
\text { Be reflexive critical thinkers \& creative practitioners who are intellectually curious, } \\
\text { imaginative \& innovative; with an ability to evaluate their own \& others' work }\end{array}$ \\
\hline $\begin{array}{l}\text { Level of informative \& } \\
\text { creative } \\
\text { exchange }\end{array}$ & 5 & $\begin{array}{l}\text { e, f } \\
\text { e: Collaborate with peers } \\
\text { f: Edit critically their own work \& } \\
\text { that of their peers }\end{array}$ & $\begin{array}{l}2.1 \\
\text { Possess information literacy skills to locate, gather, organise \& synthesise } \\
\text { information across diverse platforms to inform the understanding of the } \\
\text { communication industries }\end{array}$ \\
\hline $\begin{array}{l}\text { Expression \& presentation } \\
\text { in line with professional } \\
\text { standards }\end{array}$ & 10 & $\begin{array}{l}\text { b, c, f } \\
\text { b: Reflect upon \& analyse the } \\
\text { complexities of writing creative non- } \\
\text { fiction } \\
\text { c: Identify \& describe the accepted } \\
\text { limits of writing the real } \\
\text { f: Edit critically their own work \& } \\
\text { that of their peers }\end{array}$ & $\begin{array}{l}6.1 \\
\text { Possess well-developed skills \& proficiencies to communicate \& respond } \\
\text { effectively \& appropriately across different contexts }\end{array}$ \\
\hline
\end{tabular}


Table 6. Grade Tiers within UTS Creative Writing School

\begin{tabular}{|l|l|l|}
\hline \multicolumn{2}{|c|}{ This table compares the qualitative grade ranges } \\
\hline High Distinction & H: $85-100$ & $\begin{array}{l}\text { Work that ranges from outstanding to near faultless, requiring minimal to no } \\
\text { corrections \& gaining highly favourable feedback. } \\
\text { In short - show it to a publisher tomorrow. }\end{array}$ \\
\hline Distinction & D: $75-84$ & $\begin{array}{l}\text { Superior quality work on all the objectives of the assessment task, } \\
\text { demonstrating imaginative flair \& a sound grasp of the principles of writing. } \\
\text { Will attract some corrections \& mainly positive feedback, with suggestions for } \\
\text { improvement. } \\
\text { In short - well on its way, with potential for publication. }\end{array}$ \\
\hline Credit & C: $65-74$ & $\begin{array}{l}\text { Very promising work that reflects a good grasp of all the objectives of the task, } \\
\text { but which contains room for improvement in any or several areas. }\end{array}$ \\
\hline Pass & In short - much to admire but requiring more work before potential realised. \\
\hline Fail $50-64$ & $\begin{array}{l}\text { Acceptably meets all the requirements of the assessment task without } \\
\text { exceeding them. Only minimal evidence of imaginative flair \& originality, with } \\
\text { room for improvement in all areas. Heavy to extensive corrections \& feedback. } \\
\text { In short - aspects to admire but requiring much more revision before potential } \\
\text { realised. }\end{array}$ \\
\hline
\end{tabular}


Table 7. Original grading rubric for Assessment 2

\begin{tabular}{|c|c|c|c|c|c|}
\hline Criteria & Fail (under 50) & Pass (50-64) & Credit (65-74) & Distinction (75-84) & High Distinction (85-100) \\
\hline 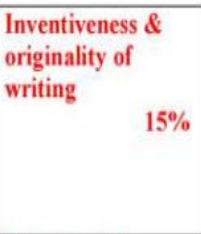 & $\begin{array}{l}\text { Unsatisfactory - no originality } \\
\text { and experimentation in } \\
\text { writing; no clear use of } \\
\text { fictional techniques and } \\
\text { elements to construct } \\
\text { narrative. }\end{array}$ & $\begin{array}{l}\text { Satisfactory - some } \\
\text { originality and } \\
\text { experimentation in } \\
\text { writing; no clear use of } \\
\text { fictional techniques and } \\
\text { elements to construct } \\
\text { narrative. }\end{array}$ & $\begin{array}{l}\text { Good - a good sense of } \\
\text { originality and } \\
\text { experimentation in writing; } \\
\text { clear use of some fictional } \\
\text { techniques and elements to } \\
\text { construct narrative but scope } \\
\text { for improvement. }\end{array}$ & $\begin{array}{l}\text { Superior - a very good } \\
\text { sense of originality and } \\
\text { experimentation in writing; } \\
\text { clear use of fictional } \\
\text { techniques and elements to } \\
\text { construct narrative. }\end{array}$ & $\begin{array}{l}\text { Outstanding - excellent sense } \\
\text { of originality and } \\
\text { experimentation in writing; } \\
\text { clear, effective and } \\
\text { sophisticated use of fictional } \\
\text { techniques and elements to } \\
\text { construct narrative. }\end{array}$ \\
\hline $\begin{array}{l}\begin{array}{l}\text { Structure \& } \\
\text { consistency of } \\
\text { writing } \\
\end{array} \quad 25 \%\end{array}$ & $\begin{array}{l}\text { Unsatisfactory - little or no } \\
\text { clarity; work is incoherent. } \\
\text { Poor spelling and grammar. } \\
\text { Does not adhere to word } \\
\text { count. }\end{array}$ & $\begin{array}{l}\text { Satisfactory - some } \\
\text { clarity but sections of } \\
\text { the work are unclear. } \\
\text { Some errors in spelling } \\
\text { and grammar. Word } \\
\text { count still over or under. }\end{array}$ & $\begin{array}{l}\text { Good - work is generally } \\
\text { quite clear with some scope } \\
\text { for improvement in terms of } \\
\text { expression. Generally good } \\
\text { spelling and grammar, word } \\
\text { count within } 10 \% \text { leeway. }\end{array}$ & $\begin{array}{l}\text { Superior - work is very } \\
\text { clear with very good } \\
\text { expression. Very minor } \\
\text { spelling or grammar issues. } \\
\text { Adheres to word count. }\end{array}$ & $\begin{array}{l}\text { Outstanding - excellent } \\
\text { clarity; no spelling or grammar } \\
\text { errors. Adheres to word count. }\end{array}$ \\
\hline $\begin{array}{l}\text { Integration of self- } \\
\text { assessment \& } \\
\text { critical feedback } \\
\qquad 20 \% \\
\text { (from peer } \\
\text { reviewing)* }\end{array}$ & $\begin{array}{l}\text { Unsatisfactory - no sense of } \\
\text { critical analysis/ engagement } \\
\text { No demonstration of critical } \\
\text { editing/writing skills. }\end{array}$ & $\begin{array}{l}\text { Satisfactory - some } \\
\text { sense of critical } \\
\text { analysis/ engagement. } \\
\text { Demonstration of some } \\
\text { critical editing/writing } \\
\text { skills but still limited. }\end{array}$ & $\begin{array}{l}\text { Good - a good sense of } \\
\text { critical analysis/ engagement } \\
\text { Demonstration of good } \\
\text { critical editing/writing skills } \\
\text { but with scope for } \\
\text { improvement. }\end{array}$ & $\begin{array}{l}\text { Superior - a very good } \\
\text { sense of critical } \\
\text { analysis/engagement. } \\
\text { Demonstration of very } \\
\text { good critical editing/writing } \\
\text { skills. }\end{array}$ & $\begin{array}{l}\text { Outstanding - excellent sense } \\
\text { of critical analysis/ } \\
\text { engagement. Demonstration of } \\
\text { sophisticated critical } \\
\text { editing/writing skills. }\end{array}$ \\
\hline $\begin{array}{l}\text { Level of } \\
\text { informative \& } \\
\text { creative exchange } \\
\qquad 15 \% \\
\text { (peer reviewing)* }\end{array}$ & $\begin{array}{l}\text { Unsatisfactory - no sense of } \\
\text { critical analysis/engagement. } \\
\text { No demonstration of critical } \\
\text { reading/editing skills }\end{array}$ & $\begin{array}{l}\text { Satisfactory - some } \\
\text { sense of critical } \\
\text { analysis/engagement. } \\
\text { Demonstration of some } \\
\text { critical reading/editing } \\
\text { skills but still limited. }\end{array}$ & $\begin{array}{l}\text { Good - a good sense of } \\
\text { critical analysis/ engagement. } \\
\text { Demonstration of good } \\
\text { critical reading/editing skills } \\
\text { but with scope for } \\
\text { improvement. }\end{array}$ & $\begin{array}{l}\text { Superior - a very good } \\
\text { sense of critical } \\
\text { analysis/engagement. } \\
\text { Demonstration of very } \\
\text { good critical } \\
\text { reading/editing skills. }\end{array}$ & $\begin{array}{l}\text { Outstanding - excellent sense } \\
\text { of critical analysis/ } \\
\text { engagement. Demonstration of } \\
\text { sophisticated critical } \\
\text { reading/editing skills. }\end{array}$ \\
\hline $\begin{array}{l}\text { Expression \& } \\
\text { presentation in } \\
\text { line with } \\
\text { professional } \\
\text { standards } \\
\qquad 25 \%\end{array}$ & $\begin{array}{l}\text { Unsatisfactory - expression is } \\
\text { unclear, little or no attention } \\
\text { paid to spelling and grammar. }\end{array}$ & $\begin{array}{l}\text { Satisfactory - an attempt } \\
\text { at clarity but with some } \\
\text { errors in spelling and } \\
\text { grammar. }\end{array}$ & $\begin{array}{l}\text { Good-expression is } \\
\text { generally clear with some } \\
\text { minor errors in spelling and } \\
\text { grammar. Scope for } \\
\text { improvement. }\end{array}$ & $\begin{array}{l}\text { Superior - expression is } \\
\text { very clear, no, or very few } \\
\text { errors in spelling and } \\
\text { grammar. }\end{array}$ & $\begin{array}{l}\text { Outstanding - expression is } \\
\text { clear and sophisticated; no } \\
\text { errors in spelling and } \\
\text { grammar. }\end{array}$ \\
\hline
\end{tabular}


Table 8. Final Instructional Rubric created by co-construction team

\begin{tabular}{|c|c|c|c|c|}
\hline & \multicolumn{4}{|c|}{$\begin{array}{l}\qquad \text { Instructional Rubric } \\
\text { This table provides a guide to producing an exceptional standard of work }(\mathrm{H}) \text {. }\end{array}$} \\
\hline & Criteria & Weight & Explain & Exemplars \\
\hline \multirow{3}{*}{ 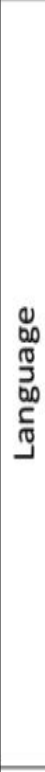 } & $\begin{array}{l}\text { Inventiveness \& } \\
\text { originality of concept }\end{array}$ & $20 \%$ & $\begin{array}{l}\text { Demonstrates a unique perspective \&/or approach in } \\
\text { sourcing a creative non-fiction narrative, \& evidence } \\
\text { of practice-led research, which includes the ethical } \\
\text { integration of primary \& secondary sources. }\end{array}$ & $\begin{array}{l}\text { Inventive \& original concept: } \\
\text { - Consider the Lobster, David Foster-Wallace } \\
\text { - Manoly, by Debora Adelaide } \\
\text { Integration of sources: } \\
\text { - Lanfranchi, John Dale }\end{array}$ \\
\hline & $\begin{array}{l}\text { Inventiveness \& } \\
\text { originality of writing }\end{array}$ & $40 \%$ & $\begin{array}{l}\text { Demonstrates an excellent sense of originality \& } \\
\text { experimentation in writing; clear, effective \& } \\
\text { sophisticated use of structure \& fictional techniques } \\
\text { (including, but not limited to: perspective, tense/s, } \\
\text { scene re-creation \& dialogue) to construct a creative } \\
\text { non-fiction narrative. }\end{array}$ & $\begin{array}{l}\text { Structure \& experimentation with form: } \\
\text { - Lanfranchi, John Dale } \\
\text { - Kate Holden, Sue Joseph } \\
\text { Inventiveness \& originality: } \\
\text { - Hiroshima, John Hersey } \\
\text { Scene setting: } \\
\text { - Schindler's List, Thomas Kenneally } \\
\text { - The Hanging, George Orwell }\end{array}$ \\
\hline & $\begin{array}{l}\text { Consistency of } \\
\text { writing }\end{array}$ & $20 \%$ & $\begin{array}{l}\text { Demonstrates a clear \& controlled narrative arc, pace } \\
\text { \& tone. Excellent written clarity; no spelling or } \\
\text { grammatical errors, correct use of tense/s \& } \\
\text { perspective. Adheres to word count. }\end{array}$ & $\begin{array}{l}\text { Most of the readings in this course, but in particular: } \\
\text { - Alan Jones, by David Leser }\end{array}$ \\
\hline \multirow{2}{*}{$\frac{3}{2}$} & $\begin{array}{l}\text { Self-assessment/ } \\
\text { critical feedback } \\
\text { integration }\end{array}$ & $5 \%$ & $\begin{array}{l}\text { Demonstrates an excellent sense of critical analysis/ } \\
\text { engagement. Demonstration of sophisticated critical } \\
\text { editing/writing skills. }\end{array}$ & $n / a$ \\
\hline & $\begin{array}{l}\text { Level of informative } \\
\& \text { creative exchange }\end{array}$ & $5 \%$ & $\begin{array}{l}\text { Demonstrates an excellent sense of critical analysis/ } \\
\text { engagement with classmates online through } \\
\text { discussion board. Demonstration of sophisticated } \\
\text { critical reading/editing/proofing skills of their work. }\end{array}$ & $n / a$ \\
\hline 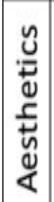 & $\begin{array}{l}\text { Expression \& } \\
\text { presentation in line } \\
\text { with professional } \\
\text { standards }\end{array}$ & $10 \%$ & $\begin{array}{l}\text { The visual presentation of the piece is professional; } \\
\text { clear, suitable to form, double-spaced, adheres to } \\
\text { word count, intuitive paragraph structure \& correct } \\
\text { footnoting \&/or referencing (if necessary). }\end{array}$ & $\begin{array}{l}\text { Most of the readings in this course, but in particular: } \\
\text { - Consider the Lobster, David Foster-Wallace } \\
\text { - Man or Myth, Mark Mordue }\end{array}$ \\
\hline
\end{tabular}


Table 9. Final Grading rubric created by co-construction team

\begin{tabular}{|c|c|c|c|c|c|}
\hline Criteria & & Lev & els of Achievement & & \\
\hline & $\begin{array}{l}\text { High Distinction } \\
\text { Work that ranges from the outstanding, } \\
\text { to near faultless, requiring minimal to } \\
\text { no corrections \& gaining highly } \\
\text { favourable feedback. }\end{array}$ & \begin{tabular}{l}
\multicolumn{1}{c}{ Distinction } \\
Superior quality work on all \\
objectives of assessment task. \\
Some corrections but mainly \\
positive feedback, with \\
suggestions for improvement.
\end{tabular} & \begin{tabular}{l}
\multicolumn{1}{c}{ Credit } \\
Promising work that reflects a \\
good grasp of all objectives of \\
task; contains room for \\
improvement in any or several \\
areas.
\end{tabular} & \begin{tabular}{l}
\multicolumn{1}{c|}{ Pass } \\
Acceptably meets all \\
requirements of assessment \\
task without exceeding them; \\
room to improve in all areas. \\
Heavy to extensive corrections \\
\& feedback. \\
\end{tabular} & $\begin{array}{l}\quad \text { Fail } \\
\text { Few come into this range, } \\
\text { which will generally only } \\
\text { reflect a student's lack of } \\
\text { effort on all counts of the } \\
\text { assessment task and/or non- } \\
\text { submission. }\end{array}$ \\
\hline & $85-100 \%$ & $75-84 \%$ & $65-74 \%$ & $50-64 \%$ & $0-49 \%$ \\
\hline $\begin{array}{l}\text { Language: originality \& } \\
\text { inventiveness of concept. }\end{array}$ & $\begin{array}{l}\text { Demonstrates a unique perspective and/ or } \\
\text { approach in sourcing a creative non-fiction } \\
\text { narrative, \& evidence of practice-led } \\
\text { research, which includes the ethical } \\
\text { integration of primary \& secondary } \\
\text { sources. }\end{array}$ & $\begin{array}{l}\text { Strongly original, with some } \\
\text { evidence of imaginative } \\
\text { development of ideas. }\end{array}$ & $\begin{array}{l}\text { Not necessarily highly original } \\
\text { concept. Evidence of the need for } \\
\text { development of ideas. }\end{array}$ & $\begin{array}{l}\text { Lacking in originality \& nil to } \\
\text { little idea of development of } \\
\text { ideas. Poor to acceptable story } \\
\text { idea or subject topic. }\end{array}$ & $\begin{array}{l}\text { No originality \& no idea of } \\
\text { development of ideas. No } \\
\text { narrative development } \\
\text { evident. }\end{array}$ \\
\hline $\begin{array}{l}\text { Language: originality \& } \\
\text { inventiveness of writing. }\end{array}$ & $\begin{array}{l}\text { Demonstrates an excellent sense of } \\
\text { originality \& experimentation in writing; } \\
\text { clear, effective \& sophisticated use of } \\
\text { structure \& fictional techniques (including, } \\
\text { but not limited to: perspective, tense/s, } \\
\text { scene re-creation \& dialogue) to construct } \\
\text { a creative non-fiction narrative. }\end{array}$ & $\begin{array}{l}\text { Strongly original, with some } \\
\text { evidence of imaginative } \\
\text { development of ideas. Very good } \\
\text { use of creative nonfiction elements. }\end{array}$ & $\begin{array}{l}\text { Well-crafted work but not } \\
\text { necessarily highly original. Some } \\
\text { use of creative nonfiction elements. } \\
\text { Lacking certain depth. }\end{array}$ & $\begin{array}{l}\text { Showing promise in one or more } \\
\text { areas but requiring specific } \\
\text { guidance as to where work may } \\
\text { be developed or improved. } \\
\text { Inconsistency or little use of } \\
\text { creative nonfiction elements. } \\
\text { Lacks depth. }\end{array}$ & $\begin{array}{l}\text { Showing no promise in any } \\
\text { area. No use of creative } \\
\text { nonfiction elements. Evidence } \\
\text { of undeveloped writing skills. }\end{array}$ \\
\hline $\begin{array}{l}\text { Language: consistency } \\
\text { of writing. } \\
\text { Weight } 20.00 \%\end{array}$ & $\begin{array}{l}\text { Demonstrates a clear \& controlled } \\
\text { narrative arc, pace \& tone. Excellent } \\
\text { written clarity; no spelling or grammatical } \\
\text { errors, correct use of tense/s \& perspective. } \\
\text { Adheres to word count. }\end{array}$ & $\begin{array}{l}\text { Consistent style, fluency of } \\
\text { expression, strong structure overall. } \\
\text { Very good spelling \& grammar, but } \\
\text { with some errors. }\end{array}$ & $\begin{array}{l}\text { Good use of punctuation, spelling } \\
\& \text { grammar; correct use \& } \\
\text { consistency of tenses. }\end{array}$ & $\begin{array}{l}\text { Poor punctuation, spelling \& } \\
\text { grammar; improper use \& } \\
\text { inconsistency of tenses. }\end{array}$ & $\begin{array}{l}\text { Incomprehensible expression, } \\
\text { poor spelling, weak grammar } \\
\text { etc. }\end{array}$ \\
\hline $\begin{array}{l}\text { Peer Review: self- } \\
\text { assessment/critical } \\
\text { feedback integration. } \\
\text { Weight } 5.00 \%\end{array}$ & $\begin{array}{l}\text { Demonstrates an excellent sense of critical } \\
\text { analysis/ engagement. Demonstration of } \\
\text { sophisticated critical editing/writing skills. }\end{array}$ & $\begin{array}{l}\text { Demonstrates a very good sense of } \\
\text { critical analysis/ engagement. } \\
\text { Demonstration of good critical } \\
\text { editing/writing skills. }\end{array}$ & $\begin{array}{l}\text { Demonstrates a good sense of } \\
\text { critical analysis/ engagement. } \\
\text { Demonstration of good critical } \\
\text { editing/writing skills. }\end{array}$ & $\begin{array}{l}\text { Some sense of critical analysis/ } \\
\text { engagement. Demonstration of } \\
\text { few critical editing/writing skills }\end{array}$ & $\begin{array}{l}\text { Failure to engage in any } \\
\text { critical analysis/ engagement. }\end{array}$ \\
\hline $\begin{array}{l}\text { Peer Review: level of } \\
\text { informative \& creative } \\
\text { exchange. }\end{array}$ & $\begin{array}{l}\text { Demonstrates an excellent sense of critical } \\
\text { analysis/ engagement with classmates } \\
\text { online through discussion board. } \\
\text { Demonstration of sophisticated critical } \\
\text { reading/editing/proofing skills of their } \\
\text { work. }\end{array}$ & $\begin{array}{l}\text { Demonstrates a very good sense of } \\
\text { critical analysis/ engagement with } \\
\text { classmates online through } \\
\text { discussion board. Demonstration of } \\
\text { very good critical reading/ editing/ } \\
\text { proofing skills of their work. }\end{array}$ & $\begin{array}{l}\text { Demonstrates a good sense of } \\
\text { critical analysis/ engagement. } \\
\text { Demonstration of good critical } \\
\text { editing/ writing skills. }\end{array}$ & $\begin{array}{l}\text { Some sense of critical analysis/ } \\
\text { engagement. Demonstration of } \\
\text { few critical editing/writing } \\
\text { skills. }\end{array}$ & $\begin{array}{l}\text { Failure to engage in any } \\
\text { critical analysis/ engagement. }\end{array}$ \\
\hline $\begin{array}{l}\text { Aesthetics: expression \& } \\
\text { presentation in line with } \\
\text { professional standards. } \\
\text { Weight } 10.00 \%\end{array}$ & $\begin{array}{l}\text { The visual presentation of the piece is } \\
\text { professional; clear, suitable to form, } \\
\text { double-spaced, adheres to word count; \& } \\
\text { demonstrates evidence of intuitive } \\
\text { paragraph structure, correct footnoting } \\
\text { and/or referencing (if necessary). }\end{array}$ & $\begin{array}{l}\text { Very good layout, presentation etc, } \\
\text { allowing for some mistakes or } \\
\text { lapses. Very good adherence to } \\
\text { length \& other presentation } \\
\text { guidelines set for the assessment. }\end{array}$ & $\begin{array}{l}\text { Acceptable to reasonably good } \\
\text { grasp of assessment task, with } \\
\text { some weakness in terms of word } \\
\text { length or other set task guidelines. } \\
\text { Layout, presentation reasonable; } \\
\text { showing need for improvement. }\end{array}$ & $\begin{array}{l}\text { Poor layout \& presentation, } \\
\text { including punctuation, needing } \\
\text { specific \& much guidance for } \\
\text { improvement. }\end{array}$ & $\begin{array}{l}\text { Work that is impossible to } \\
\text { correct due to poor expression } \\
\text { \& overall presentation. } \\
\text { Failure to meet all assessment } \\
\text { task guidelines, including } \\
\text { word length. }\end{array}$ \\
\hline
\end{tabular}

